\title{
Mining Engineering Education Pre and Post the COVID Pandemic and Some Ideas for the Future
}

\author{
A.J.S. (Sam) Spearing ${ }^{1}$, Jixiong Zhang ${ }^{1}$, Steve Hall ${ }^{2}$, and Liqiang $\mathrm{Ma}^{1}$ \\ ${ }^{1}$ School of Mines, China University of Mining \& Technology, 1 Daxue Road, Xuzhou City, Jiangsu \\ Province 221116, China \\ ${ }^{2}$ School of Engineering \& Technology, Central Queensland University, Rockhampton North, Bruce \\ Highway, Rockhampton, QLD 4702
}

\begin{abstract}
The pandemic forced all businesses globally to rethink operations. Higher education institutions experienced similar disruptions, especially those with large cohorts of foreign students. The technology employed in the mining industries, it is evolving rapidly and requires novel and more specialized expertise in the face of an impending skilled labour shortage. This paper strategizes how mining education could improve and align with the needs of the mining industry and students, post-pandemic.
\end{abstract}

\section{Introduction}

It has been, and still is the case, that an ever-advancing global society is impossible without being totally dependent on extractive mineral industries. Unlike surplus, low wage careers that are becoming redundant due to advances in technology, and therefore, low labour demand, mining engineers will remain relevant regardless of broader societal perceptions [1]. As the industries moves forward, graduates with different and varied skill sets will be needed to navigate mining challenges such as:

- Remote mine sites in developing countries, with limited infrastructure, resources, and political risk.

- Deeper mines chasing typically lower-grade deposits with more complex geology.

- The "no or limited access" remote mine, e.g., in-situ and solution, sub-sea and asteroid or other planetary mines.

- Economically competitive mineral processing and mining methods on an international scale.

- International investor and labour interests and relations.

- Effective community engagement, interaction and relations.

- The ever more complex and time-consuming permitting process.

- Government and international interests regarding mineral deposits, technologies, and national supply security of critical minerals.

- Environmental and health and safety compliance.

Social and environmental initiatives and the social licence to operate (green mining). The mining industry is changing very rapidly, and it is embracing the technology from the $4^{\text {th }}$ Industrial Revolution specifically:

- Real time monitoring and data analytics 
- Automation.

- Robotics.

- Artificial intelligence.

The mining industry is now focussing on green mining and sustainability. Society needs a circular mining economy, which may be difficult to achieve without some form of global oversight. Mines need to maximize production to maintain profitability and cannot be easily "turned off and on", and for a circular mining economy a balance is needed between waste utilisation, recycling, repurposing and producing new mined product.

Prior to COVID, Spearing and Hall in 2016 [1] suggested that the traditional method of attending lectures during a whole semester will probably need to change. On-line teaching appeared to be on the rise, and the pandemic seems to have accelerated this delivery mode. This is so that students can work nearly full-time with short bursts of intensive contact time for lectures and laboratories and the remainder on-line using high quality internet-based audio-visual delivery. The current system of 12-14 weeks of contact time per semester would change to say only 4 to 6 weeks in one or two-week sections, thus allowing the student to work in their chosen mining resources career whilst obtaining a tertiary education. This would assist the future students by reducing the effective cost of obtaining their degree and help their employers by creating truly job ready and fully trained graduates.

With the advent of covid, almost all academic delivery globally has been done remotely either live or at leisure on-line (depending on the time zones between the university and any foreign students not on site. The overall result has not been as effective as contact classroom delivery but it has been adequate.

\section{The current status of English-speaking mining education globally}

The current downsizing trend of academic mining institutions particularly in Western Countries, is reflected in a vicious cycle of reduced graduates, resulting in fewer academic faculty or stagnant academic hiring. Small enrolment and niche programs will be under continued pressure as universities transition into the post-COVID era of remote work and teaching whilst maintaining pre-COVID academic standards and policy.

A critical complicating issue that makes mining staff planning and related education unique, is that it is so closely linked to economic boom and bust cycles of the industry. This means that maintaining an academic labour force and new talent for the mines will continue to be an ongoing challenge without changes to government-industry-academic collaborations and indirect efforts such as more effective teaching methods. Take for example Australia, where mining graduates have declined since a peak in 2015 by nearly $70 \%$, as shown in Figure 1 [2].

It is apparent that the current trend will not meet labour market demand. For example, the Australian mining and related industries need 160 mining graduates a year [3]. This estimate was made in a publication by Knights in 2019 , and the year following only $65 \%$ of that demand was reached according to Figure 1. Positions are either left unfilled or new graduate engineers from other countries often with little or no mining background must be retrained at a substantial cost. For example, the Society for Mining Metallurgy and Exploration quotes an internal report by McCarter in 2005, that the relative cost to retrain a civil engineer to do a mining engineers job is almost $600 \%$ [4]. 


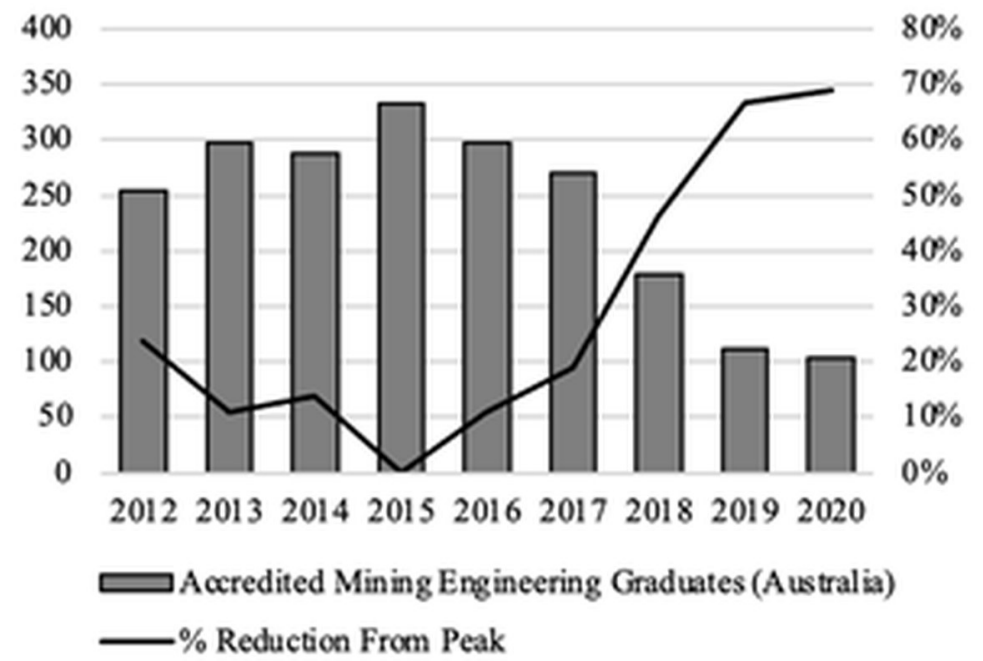

Fig. 1. Accredited mining engineering graduates in Australia [3].

Cost of education is also a concern, especially in western countries where it is not uncommon for student debt repayment plans to exceed the cost of a thirty-year home mortgage payment. Evidence is presented in Figure 2, which accompanies Table 1, and presents the annual tuition costs for students at a sample $(n=34)$ of select mining programs, using 2019 data (and currency exchange rates). In an unpublished study by Spearing in 2019, the following is relevant to illustrate how the number of academics in selected global mining programs is generally low:

Table 1. No of academics in selected mining engineering programs.

\begin{tabular}{|c|c|c|c|}
\hline Country & $\begin{array}{c}\text { No of programs } \\
\text { reviewed }\end{array}$ & $\begin{array}{c}\text { Average no of full- } \\
\text { time academics }\end{array}$ & $\begin{array}{c}\text { Maximum number of } \\
\text { academics in a program }\end{array}$ \\
\hline US & 14 & 8.4 & 18 \\
\hline Canada & 7 & 8.1 & 15 \\
\hline Australia & 6 & 6.5 & 8 \\
\hline UK & 1 & 11.0 & NA \\
\hline India & $3^{*}$ & 13.3 & 20 \\
\hline South Africa & 2 & 13.0 & NA \\
\hline China & 1 & +100 & 14 \\
\hline
\end{tabular}

* Only includes the top 3 mining programs (all have Indian Institutes of Technology status).

Fig. 2 shows the annual tuition costs (using 2019 data and exchange rates) of the programs considered in Tab. 1. 


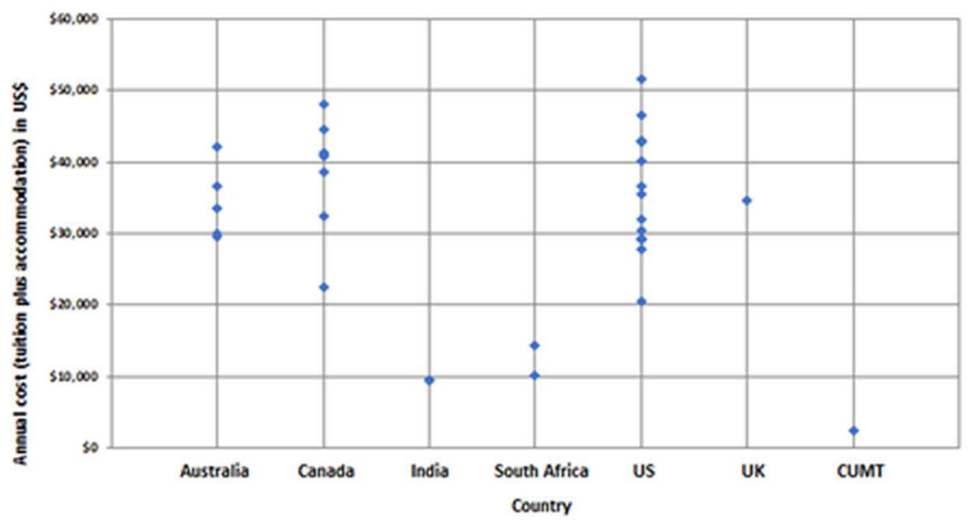

Fig. 2. 2019 Annual tuition cost range by country for foreign students (includes fees where openly specified).

Choosing where to study is a very important decision that perspective students must make and the main factors that influence this are academic credentials and financial situation.

Foreign students with excellent academic potential and/or those with the necessary financial resources have been studying in traditional first world countries for decades. This was historically probably because the tertiary institutions in their home countries where perceived to be not as well-resourced and a local accreditation system, if it was established, tended not to be widely recognised internationally.

It was therefore expected that mining students were drawn to foreign education in countries such as the US, UK, Australia and Canada. This had the high potential for paid internships during study, and job opportunities after graduation. Seemingly, the cost effectiveness and established metrics (e.g. student/faculty ratios), are less of a consideration in mining education than perceived historical eminence.

The lack of globally recognised engineering programs started to be resolved in 1989, when the Washington Accord [5] was signed by certain countries and has since continued to expand to include more countries. This is an agreement between accreditation organizations in various countries that then recognizes tertiary-level engineering qualifications in all signature countries.

According to the International Engineering Alliance [5], qualifications accredited or recognized by other signatories are recognised by each signatory as being substantially equivalent to accredited or recognised qualifications within its own jurisdiction. The current list of accredited signatory member countries is:

- Australia - Represented by Engineers Australia (EA) (Founder signatory in 1989).

- Canada - Represented by Engineers Canada (EC) (Founder signatory in 1989).

- China - Represented by China Association for Science and Technology (CAST) (Signed in 2016).

- China Hong Kong - Represented by The Hong Kong Institution of Engineers (HKIE) (Signed in 1995).

- Chinese Taipei - Represented by Institute of Engineering Education Taiwan (IEET) (Signed in 2007).

- Costa Rica - Represented by Colegio Federado de Ingenieros y de Arquitectos de Costa Rica (CFIA) (Signed in 2020).

- India - Represented by National Board of Accreditation (NBA) (Signed in 2014).

- Ireland - Represented by Engineers Ireland (EI) (Founder signatory in 1989).

- Japan - Represented by Japan Accreditation of Board for Engineering Education (JABEE) (Signed in 2005).

- Korea - Represented by Accreditation Board for Engineering Education of Korea (ABEEK) (Signed in 2007). 
- Malaysia - Represented by Board of Engineers Malaysia (BEM) (Signed in 2009).

- New Zealand - Represented by Engineering New Zealand (EngNZ) (Founder signatory in 1989).

- Pakistan - Represented by Pakistan Engineering Council (PEC) (Signed in 2017).

- Peru - Represented by Instituto de Calidad y Acreditacion de Programas de Computacion,

- Ingenieria y Tecnologia (ICACIT) (Signed in 2018).

- Russia - Represented by Association for Engineering Education of Russia (AEER) (Signed in 2012).

- Singapore - Represented by Institution of Engineers Singapore (IES) (Signed in 2006).

- South Africa - Represented by Engineering Council South Africa (ECSA) (Signed on 1999).

- Sri Lanka - Represented by Institution of Engineers Sri Lanka (IESL) (Signed in 2014).

- Turkey - Represented by Association for Evaluation and Accreditation of Engineering Programs (MÜDEK) (Signed in 2011).

- United Kingdom - Represented by Engineering Council United Kingdom (ECUK) (Founder signatory in 1989).

- United States - Represented by Accreditation Board for Engineering and Technology (ABET) (Founder signatory in 1989).

Worldwide, there are over five million college students studying in places other than their home country. International students typically pay higher fees than domestic students, and provide an essential and sometimes sizable revenue stream to institutions [6]. Australian Universities have been dependent on foreign students for many years. In 1990, there were just 24,990 international students studying in Australia. By 2018, that number had risen by 35 times, a growth sustained by double-digit increases year after year. Until the pandemic, higher education was Australia's third-largest export, worth AUS\$34.9 billion (US\$24.7 billion), behind only iron ore and coal [7].

\subsection{Global mining and minerals ranking}

Mining and minerals programs are only ranked by the QS Ranking System and only $30 \%$ of the ranking is data driven whereas the balance is based on opinion. Ranking consists of 4 components:

- How other academics in mining and minerals outside the specific university rank the academics at the specific university $(50 \%)$.

- How employers of graduates from a specific University rank them (20\%).

- The h-index for publications (15\%).

- The citation index (15\%).

The publications and citations run off Scopus categories and it currently is not well defined as it includes papers from the following:

- Mining and Minerals - not certain if this is a current Scopus topic.

- Geology (ASCJ 1907).

- Geophysics (ASCJ 1908).

- Engineering Geology \& Geotechnical Engineering (ASCJ 1909).

- Geochemistry \& Petrology (ASJC 1906) - this appears only marginally relevant.

- Ocean Engineering (ASJC 2212) - this does not appear a relevant topic.

It is hoped that Scopus better focusses papers relevant to mining and minerals so that only applicable topics are included.

It is evident that programs offered in English are dominant, with over half the top 50 global mining and minerals programs as shown in Figure 3. English language mining engineering programs are also offered in many countries including China, Japan, Germany, Turkey, Chile, Saudi Arabia, Ghana, Malawi \& Zambia. 


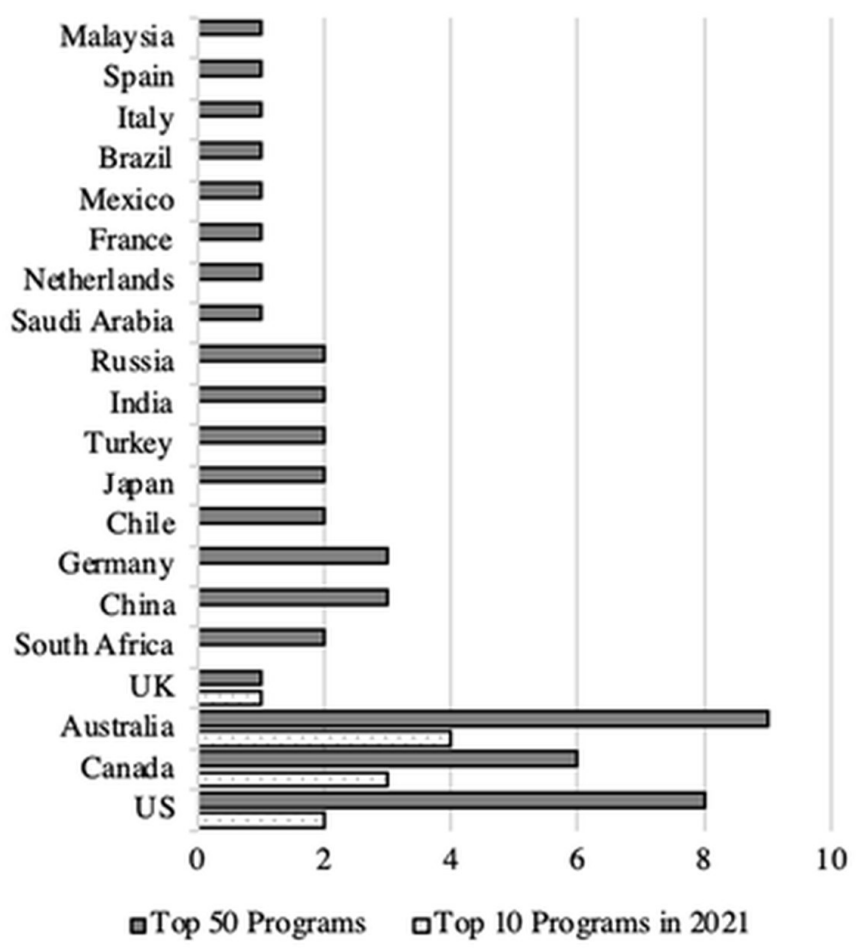

Fig. 3. Program rankings for select countries.

\subsection{Future skills required}

As the mining industry embraces new technologies that are essential for improved safety and productivity in the future, the formal tertiary skills required need to be updated too as a matter of some urgency. As the larger mining companies tend to operate in multiple countries now and this trend seems to be increasing, graduate mobility is becoming more important. This means that the soft skills (Table 2) are more essential, especially cultural awareness and multiple language skills. Students from foreign non-English speaking countries, appear far more proficient in languages than English speaking students, which may give them a potential employment edge in the future.

Table 2. The mining engineering graduate skills future needs [1].

\begin{tabular}{|c|c|c|}
\hline Basic Skills & Technical Skills & Soft Skills \\
\hline Safety & Mine design & Management \\
\hline English & Automation & Community relations \\
\hline Structural geology & Ventilation and services & Communication \\
\hline Mathematics and statistics & Rock mechanics & Sustainability \\
\hline Problem solving and logic & Rehabilitation and closure & Risk management \\
\hline Mine and asset management & Processing & Social responsibility \\
\hline Mining law & Mine planning & Cultural awareness \\
\hline
\end{tabular}




\begin{tabular}{|c|c|c|}
\hline Mine finance and evaluation & Instrumentation & $\begin{array}{c}\text { Global experience and cultural } \\
\text { awareness }\end{array}$ \\
\hline
\end{tabular}

As the larger mining companies tend to operate in multiple countries now and this trend seems to be increasing, graduate mobility is becoming more important. This means that the "soft skills" (an unfortunate term since these skills are becoming even more essential, especially cultural awareness and multiple language skills). Students from foreign nonEnglish speaking countries, appear far more proficient in languages than English speaking students, which may give them a potential employment edge in the future.

\section{Possible future tertiary educational models}

One method to meet the needs of future students and save the important but financially uneconomic small enrolment niche university programs, especially mining, is the introduction of new teaching models.

Flexible pathways via staged qualifications in mining-related disciplines will become more important as the skilled labour demand increases. Retraining via full-time 4 or 5-year degree programs is unlikely, and recognition of prior learning and skills will be important within much shorter diploma or postgraduate qualifications. These qualifications will increasingly combine skills development with relevant foundational knowledge.

For example, in Australia, the future of the Technical and Further Education (TAFE) sector and how it, or others, bridge the divide between it and the conventional Higher Education Sector is critical to developing the highly skilled and knowledgeable workforce that the mining industry will need, but creating easy pathways. There is a much greater mobility from the TAFE sector to the University sector; post-degree or during degree study, to acquire industry-specific skills than is often realised. Dual-sector institutions providing quality, flexible programs, possibly combining Advanced Diplomas with Associate Degrees, will allow people to move between industry sectors more quickly, especially within the mineral resources sector. The changes to the requirements of holders of statutory positions in the industry will pose opportunities for institutions that can work with employers to combine practical experience and relevant qualifications.

International mobility will increase with students studying across borders as part of their qualifications, rather than moving from undergraduate directly to postgraduate studies, which is more common today. This could result in increasing numbers of internationally mobile students, studying for shorter periods of time at any one institution. In addition to different pedagogical as well as cultural backgrounds this will further challenge the academic and support staff. Academic staff will therefore have to embrace often disruptive technologies inside and outside of the classroom. The use of world-class experts to deliver specialized courses would be highly cost effective and provide excellent upskilling or formal qualification classes.

The challenge of ensuring that mining companies have adequate numbers of mining resources graduates to meet their needs might require a modified approach with greater use of internship period during study i.e., the "Co-Op" Model.The industry generally requires lifelong learners hence the need for relevant courses for upskilling employees and postgraduate qualifications. Universities need to offer these in block-teaching-mode for inperson students and remotely or on-line for employees on mines for their convenience and cost effectiveness.

\subsection{Possible future undergraduate mining engineering models}

As mentioned, with the advent of COVID, almost all academic delivery has been done remotely. The result has probably not been as effective as contact classroom delivery, but it 
appears to have been adequate, as students have continued with their studies in spite of the challenges. The traditional method of attending lectures during a whole semester will probably need to change so that students can work nearly full-time with short bursts of intensive contact time for lectures and laboratories and the remainder on-line using high quality internet-based audio-visual delivery [1]. The typical 12 to 14 weeks of contact time per semester would change to only typically 4 to 6 weeks, in probably two-week sections, thus allowing the student to work in their chosen mining resources career whilst in parallel obtaining a tertiary education.

Currently, the mining engineering status quo is not financially effective for the universities with low enrolment and resultant poorly resourced programs. It is also not an effective way for today's students, having to pay high tuition and fees, plus earn little to nothing during the four years of study. The old Co-Op Model was basically one semester in college and one semester working on site. A more modern and effective method could be mines employing people straight from school, and after a probation period of six months, providing paid (or even unpaid) time to study say 2-3 full university courses every half year. These could be offered in two-week-block periods, either at the university, remotely (live), or on-line. This method would also be ideal for mature students who are already employed and have family responsibilities, where leaving employment for four years is impractical. This modified Co-Op model could have the following advantages for all parties involved, as shown in Table 3.

Table 3. Advantages for each interested party

\begin{tabular}{|c|c|c|c|}
\hline Student & Industry & Academia & Academics \\
\hline $\begin{array}{c}\text { Reduced debt, } \\
\text { industry experience } \\
\text { and fully employed } \\
\text { before graduation }\end{array}$ & $\begin{array}{c}\text { Meets the demands of } \\
\text { their labour shortage } \\
\text { through co-ops, and } \\
\text { ensures they meet } \\
\text { their company } \\
\text { expectations and } \\
\text { culture, while } \\
\text { targeting effectively } \\
\text { under-represented } \\
\text { groups }\end{array}$ & $\begin{array}{c}\text { Cost effective, as it } \\
\text { minimizes full-time } \\
\text { staff which teach the } \\
\text { basic courses and } \\
\text { satisfies accreditation } \\
\text { processes; and uses } \\
\text { global experts to } \\
\text { teach the more } \\
\text { specialized courses }\end{array}$ & $\begin{array}{c}\text { Less financial } \\
\text { pressure and more } \\
\text { time to devote } \\
\text { towards research and } \\
\text { paper submissions; } \\
\text { plus spend time in } \\
\text { industry to maintain } \\
\text { current knowledge }\end{array}$ \\
$\begin{array}{c}\text { Mining experience } \\
\text { improves classroom } \\
\text { performance (e.g., } \\
\text { ventilation, rock } \\
\text { mechanics) }\end{array}$ & $\begin{array}{c}\text { At six courses a year, } \\
\text { co-op students are } \\
\text { away twelve weeks a } \\
\text { year at most, much } \\
\text { less if studying on- } \\
\text { line or remote }\end{array}$ & $\begin{array}{c}\text { Firmer enrolment data } \\
\text { based on the co-op } \\
\text { students employed by } \\
\text { mining companies } \\
\text { that often favour one } \\
\text { particular university } \\
\text { for its students for } \\
\text { example }\end{array}$ & $\begin{array}{c}\text { Block teaching is } \\
\text { intensive, but two- } \\
\text { weeks at a time } \\
\text { followed by a long } \\
\text { break can be } \\
\text { advantageous }\end{array}$ \\
$\begin{array}{c}\text { Course fees could get } \\
\text { paid for by employer } \\
\text { or paid from mine } \\
\text { salary }\end{array}$ & $\begin{array}{c}\text { The graduated student } \\
\text { is prepared for work } \\
\text { and is well rounded } \\
\text { both theoretically and } \\
\text { practically }\end{array}$ & $\begin{array}{c}\text { Improved program } \\
\text { finances }\end{array}$ & $\begin{array}{c}\text { Academics can also } \\
\text { use industry experts } \\
\text { for short guest } \\
\text { lectures which are } \\
\text { usually pro bono }\end{array}$ \\
\hline
\end{tabular}




\subsection{Possible future postgraduate mining engineering models by coursework}

Moving forward, it would seem economically and logistically beneficial if all postgraduate courses were delivered in a hybrid model, whereby methods of block contact teaching, remote, and on-line teaching are combined. On-site residence at the university would be as limited as possible and include any relevant and required lab work.

Students should have the option to take these courses purely for upskilling or alternatively for a postgraduate qualification. The postgraduate option could be paying an additional nominal fee for assessments such that the course could be used as part of a postgraduate degree by coursework. Instead of specializing in a specific discipline (like mining or civil engineering), "stackable" degrees could be offered based on postgraduate courses from numerous disciplines (such as mining, mineral economics, environmental and human relations).

\section{Conclusions}

Based on the enrolment trends in niche and specialized programs such as mining, the costs and effectiveness of remote teaching, the following conclusions can be made:

- Whilst remote or on-line teaching may not be as effective as full contact, it has been proven to work during the pandemic, and should be more cost effective for the students and the $\bullet$ universities.

A Co-Op model for undergraduate mining engineering education appears to have many advantages and could better meet the expectations of future students. Such a system offers students much more cost-effective options and not just in their country of residence.

- It would seem to make sense to move to a hybrid teaching model for all postgraduate and upskilling courses. This would consist of block taught courses, simultaneously delivered live remotely and on-demand. An assessment could also be an extra for those wanting postgraduate credit for courses.

- Postgraduate degrees should become stackable general engineering degrees with different focus specializations.

- Due to the increasing complexity of mining, other degrees with a certified speciality (e.g., minor in mining) are needed moving forward.

\section{References}

1. A.J.S. (Sam) Spearing, S. Hall, AusIMM Bulletin Magazine, August, 26-28 (2016)

2. P. Knights, Australian graduate mining engineering statistics (Australian Network of Mining Engineering Educators, 2021). (to be published)

3. P. Knights, Short term supply and demand of graduate mining engineers in Australia (Mineral Economics, 2019)

4. Society for Mining, Metallurgy \& Exploration. (2013, 3). Federal Support for U.S. Mining Schools. URL: https:/www.smenet.org/What-We-Do/TechnicalBriefings/Federal-Support-for-U-S-Mining-Schools

5. International Engineering Alliance. Washington Accord (International Engineering Alliance, Washington, 2021)

6. S. Hall, The global view of the pandemic's effect on higher education (The Century Foundation, 2020)

7. B. Kunkler, Australian universities were sick before the pandemic (Jacobin, 2020) 